Portland State University

PDXScholar

\title{
Trust in Organization as a Moderator of the Relationship between Self-efficacy and Workplace Outcomes: A Social Cognitive Theory-Based Examination
}

Adnan Ozyilmaz

Mustafa Kemal University

Berrin Erdogan

Portland State University, berrine@sba.pdx.edu

Aysegul Karaeminogullari

Istanbul University

Follow this and additional works at: https://pdxscholar.library.pdx.edu/busadmin_fac

Part of the Business Administration, Management, and Operations Commons, and the Organizational Behavior and Theory Commons

Let us know how access to this document benefits you.

\section{Citation Details}

Ozyilmaz, Adnan; Erdogan, Berrin; and Karaeminogullari, Aysegul, "Trust in Organization as a Moderator of the Relationship between Self-efficacy and Workplace Outcomes: A Social Cognitive Theory-Based Examination" (2018). Business Faculty Publications and Presentations. 89.

https://pdxscholar.library.pdx.edu/busadmin_fac/89

This Post-Print is brought to you for free and open access. It has been accepted for inclusion in Business Faculty Publications and Presentations by an authorized administrator of PDXScholar. Please contact us if we can make this document more accessible: pdxscholar@pdx.edu. 
Running head: TRUST IN ORGANIZATION

\title{
Trust in Organization as a Moderator of the Relationship between Self-efficacy and Workplace Outcomes: A Social Cognitive Theory-Based Examination
}

\author{
Adnan Ozyilmaz* \\ Department of Business Administration \\ Mustafa Kemal University \\ Hatay, Turkey \\ ozyila@yahoo.com \\ Berrin Erdogan \\ School of Business Administration \\ Portland State University \\ Portland, Oregon, U.S.A. \\ berrine@pdx.edu \\ Aysegul Karaeminogullari \\ School of Business Administration \\ Istanbul University \\ Istanbul, Turkey \\ aysegulk@istanbul.edu.tr
}

How to cite

Ozyilmaz, A., Erdogan, B. and Karaeminogullari, A. (2017), Trust in organization as a moderator of the relationship between self-efficacy and workplace outcomes: A social cognitive theory-based examination. Journal of Occupational and Organizational Psychology. doi:10.1111/joop.12189 


\title{
Trust in Organization as a Moderator of the Relationship between Self-efficacy and Workplace Outcomes: A Social Cognitive Theory-Based Examination
}

\begin{abstract}
Drawing on a social cognitive theory perspective, we contend that an employee's trust in oneself, or self-efficacy, will interact with the individual's trust in the system, or trust in organization, to predict job attitudes and behaviors. Specifically, we expected that self-efficacy would have stronger effects on job attitudes (job satisfaction and turnover intentions) and behaviors (task performance and organizational citizenship behaviors) to the degree to which employees perceive high levels of trust in organization. Using data collected from 300 employees and their respective supervisors at a manufacturing organization in Turkey across three waves, we found that self-efficacy had more positive effects on job satisfaction, task performance, and citizenship behaviors when trust in organization was high. Interestingly, self-efficacy had a positive effect on turnover intentions when trust in organization was low, indicating that high trust in organization buffered the effects of self-efficacy on intentions to leave. The results suggest that the motivational value of trust in oneself is stronger to the degree to which employees also have high trust in the system, whereas low trust in system neutralizes the motivational benefits of selfefficacy.
\end{abstract}

Keywords: Self-efficacy, role breadth self-efficacy, trust in organization, social cognitive theory, job satisfaction, turnover intentions, employee performance. 


\section{Practitioner Points}

- $\quad$ Practicing managers should not only invest in increasing self-efficacy of their employees, but also invest in building trust to improve employees’ attitudes, behaviors, and performance. This is because when employee trust in organization is high, employee self-efficacy has greater potential to have a positive influence over job satisfaction, task performance, and organizational citizenship behaviors.

- $\quad$ Self-efficacy may actually increase an employee's desire to leave the organization when organizational conditions are unfavorable, such as in the case of low trust in the organization. Practicing managers should be aware that employees who have high levels of confidence may be at higher risk of turnover when they are unhappy with the organization. 


\section{Trust in Organization as a Moderator of the Relationship between Self-efficacy and Workplace Outcomes: A Social Cognitive Theory-Based Examination}

Understanding how to improve employee attitudes, work related behaviors, and performance still remains a major goal for scholars and practitioners alike. Social cognitive theory (SCT) has generated a great appreciation for the importance of self-efficacy on many indicators of workplace effectiveness and job attitudes (Bandura, 1997, 2012). Research in this realm has focused primarily on self-efficacy - a person's felt confidence to perform a particular task - and has been guided by the assumption that self-efficacy affects choice behaviors, persistence of effort, perseverance in setbacks, and self-aiding and self-hindering thought patterns of employees (Bandura, 1988a). Therefore, self-efficacy is regarded as a key predictor of job performance (Stajkovic \& Luthans, 1998a) and job attitudes (Judge \& Bono, 2001). Believing in one's capabilities and in oneself is regarded as a critical aspect of one's self concept, as evidenced by the inclusion of self-efficacy in higher level personality constructs such as core self-evaluations (Judge \& Bono, 2001) and psychological capital (Luthans, Avolio, Avey, \& Norman, 2007). Positive organizational behavior (POB) regards self-efficacy as a state-like construct that has significant effects on employees' work related attitudes and behaviors (Luthans \& Avolio, 2009; Luthans \& Youssef, 2007).

Although scholars have studied the direct effects of self-efficacy on individual attitudes and behaviors, investigating the boundary conditions of self-efficacy also is important in order to understand the limits of its effects and the contexts in which it makes a greater contribution to one's attitudes and actions. SCT provides a strong theoretical base for the potential boundary conditions by emphasizing that individuals’ psychosocial functioning is a result of the interaction between individual' motivation and the organizational environment (Bandura, 1997, 2001, 
2012). For example, a meta-analysis by Judge, Jackson, Shaw, Scott, and Rich (2007) showed that the effects of self-efficacy on performance were stronger when the task was low in complexity. In other words, it seems that self-efficacy does not exert uniform influence over employee attitudes and actions. In fact, there are even studies indicating that self-efficacy has a negative effect on individual performance (e.g., Vancouver \& Kendall, 2006). Understanding when and under what conditions self-efficacy is a more relevant influence over job attitudes and behaviors matters because an omission of the contextual factors would overestimate the effects of self-efficacy, and give rise to the misleading assumption that self-efficacy is the key to effectiveness and satisfaction at work, whereas the reality may be more complicated. Since Stajkovic and Luthans (1998a) identified the importance of understanding when self-efficacy is related to performance and other outcomes, few studies focused on moderators of self-efficacy (cf. O’Neill \& Mone, 1998; Raghuram, Wisenfeld, \& Garud, 2003).

In this study, we theorize that employees’ confidence in themselves (self-efficacy) should be jointly studied along with their confidence in the context they operate in (trust in organization) and argue that the role played by one's self efficacy will be stronger when the individual operates in a context that is trustworthy. Trust in organization represents a context within which more positive attitudes/perceptions, higher performance, and cooperation are highly likely to happen (Alfes, Shantz, \& Truss, 2012; Brown, Crossley, \& Robinson, 2014). Accordingly, trust in organization should facilitate the influence of self-efficacy on work-related outcomes by impacting how employees assess the future behavior of the organization (consistent and predictable, as well as benevolent; Dirks \& Ferrin, 2001). Through influencing the employee’s assessment of organizations’ future actions or behaviors, trust in organization decreases some of the accompanying ambiguity of the consequences of one's actions (Dirks \& 
Ferrin, 2001). In other words, belief in one's capabilities should make more of a difference in one's actions and attitudes when the employee believes that the context in which they operate is predictable and in general will be supportive of employee actions.

In this study, we develop a model where we theorize that the relationship between selfefficacy, attitudinal outcomes (job satisfaction and turnover intentions) and workplace behaviors (task performance and organizational citizenship behaviors (OCBs)) is contingent on trust in organization. We chose these outcomes, because they represent some of the most frequently studied outcomes in organizational behavior, and capture important aspects of job attitudes as well as different dimensions of effectiveness at work. We consider trust in organization as a relevant moderator following Bandura’s (2012) contention that under strong disincentives or significant social and physical constraints, the individuals will be less likely to act on their selfefficacy belief. We apply these ideas to self-efficacy theory to explain how employees' trust in organization moderates the relationship between self-efficacy and work related outcomes.

We aim to make two theoretical contributions to the literature. First, we examine the boundary conditions of the effects of self-efficacy on employees’ workplace outcomes. Based on the theoretical prominence of organizational trust as a moderator in the relationship between selfefficacy and work related outcomes (Crossley, Cooper, \& Wernsing, 2013; Dirks \& Ferrin, 2001, 2002), we incorporate organizational trust theory with social cognitive theory (including selfefficacy theory) to identify its boundary conditions. Prior research has addressed the relevance of investigating self-efficacy as a motivational construct to predict task performance in the workplace (Chen, Casper, \& Cortina, 2001; Raub \& Liao, 2012; Stajkovic \& Luthans, 1998a). What has not yet been investigated is whether the relational context makes a difference within this framework. A lack of trust in the work environment may serve as a barrier, creating high 
vulnerability, causing employees to be cautious, resulting in restriction of efforts, and thus diminishing the potential benefits of one’s self-efficacy (Bandura, 1988a, 2001; Dirks \& Ferrin, 2001; Kramer, 1999; Mayer, Davis, \& Schoorman, 1995; Stajkovic \& Luthans, 1998a). In contrast, a high trust environment should serve as a facilitator, as it signals that the context is benevolent and predictable, amplifying the positive effects of self-efficacy.

Second, we contribute to the organizational trust literature where previous empirical research has considered trust in organization mainly as a direct predictor of employee attitudes, behaviors, and performance (Aryee, Budhwar, \& Chen, 2002; Colquitt, Scott, \& LePine, 2007). By exploring how trust in organization serves as a moderator of a person's confidence in oneself, we provide empirical evidence to the theoretical proposition (Crossley et al., 2013; Dirks \& Ferrin, 2001) that trust in organization moderates the relationship between motivational constructs and workplace behaviors, a proposition that has not been empirically investigated. Thus, we aim to add to prior literature by examining trust as a catalyst for the effects of internal motivational states, as an addition to past research examining its own motivational value.

\section{Theory and Hypotheses}

\section{Social Cognitive Theory and Trust in Organization}

According to Bandura (1997), self-efficacy is “an individual’s conviction (or confidence) about his or her abilities to mobilize the motivation, cognitive resources, and courses of action needed to successfully execute a specific task within a given context” (Stajkovic \& Luthans, 1998b: 66). This means that employees "with the same skills may, therefore, perform poorly, adequately, or extraordinarily, depending on whether their self-beliefs of efficacy enhance or impair their motivation and problem-solving efforts” (Wood \& Bandura, 1989: 364). In this study, our focus is on role breadth self-efficacy (RBSE, Parker, 1998), which focuses on one’s 


\section{TRUST IN ORGANIZATION}

general confidence to successfully complete a broad range of tasks. RBSE is the type of selfefficacy that is regarded as a core component of psychological capital (PsyCap, Huang \& Luthans, 2015; Luthans, Avey, Avolio, Norman, \& Combs, 2006), which refers to personal resources available to individuals to cope with demands.

Schaubroeck, Shen, and Chong (2017) contended that RBSE goes beyond assessing one's competence in technical components of the job, and instead also includes efficacy regarding one's participation as a team member to the group, so that the individual contributes to the group’s overall functioning. More specifically, RBSE means analyzing a long-term divisional or organizational problem to ascertain a solution, innovating processes and procedures for one’s work area, and providing recommendations to management regarding ways to improve the working of one's department or section. It also includes behaviors such as contributing to discussions and meetings about the organization's strategy, developing a plan to spend money in one's department, and aiding to set goals in one's work area. RBSE has been related to both job performance and job satisfaction in a variety of settings (Luthans et al., 2007; Wu, Parker, Wu, \& Lee, 2017).

SCT partly recognizes self-efficacy as a self-regulatory mechanism to control individuals’ motivation, performance, attitudes, and behaviors because "much of the knowledge and behaviors of organizational participants is generated from the organizational environment” which is not under the control of employees (Stajkovic \& Luthans, 1998b: 63). This means that the organizational environment is another influence process on employees. Therefore, not considering the internal organizational environment aspect of SCT provides only an incomplete understanding of human thought and action in organizational settings. Because imposed and constructed environments are not under the control of employees, employee motivation and 
behavior may be better understood with joint consideration of internal motivational states as well as the relational context in which behaviors and actions take place.

\section{Trust in Organization}

Trust in organization is defined as the confident, positive expectations of employees about the intention and behavior of multiple constituencies of an organization regarding the organization's conduct, motives, and intentions in an organizational setting (Colquitt \& Rodell, 2011; Fulmer \& Gelfand, 2012; Gabarro \& Athos, 1976; Lumineau, 2017; McAllister, 1995). Positive expectations are regarded as cognitive trust (Dirks \& Ferrin, 2002; McAllister, 1995) that involves employees’ beliefs about organizational integrity, consistency and predictability, and having positive motives toward the employee (Gabarro \& Athos, 1976; Lumineau, 2017). The multiple constituencies refer to owners, top management, leader(s), and other decision makers of the organization as a whole (Cropanzano, Anthony, Daniels, \& Hall, 2017; Kramer, 2010). Employee trust in organization is an internal environmental element that sets up the expectations of employees about their organizations (Colquitt et al., 2007; McEvily, Perrone, \& Zaheer, 2003).

Trust in organization represents an employee's understanding of the relationships/exchanges with their organization because trust develops as a result of accumulated experiences with and knowledge about the organization (Dirks \& Ferrin, 2001). Therefore, trust in organization can determine the relevance of internal motivational states on outcomes by setting up the expectations about how the organization will react to one's efforts (Brown et al., 2014; Cropanzano et al., 2017). Specifically, trust in organization affects how an employee assesses the future behavior of an organization in an exchange relationship (Crossley et al., 2013; Dirks \& Ferrin, 2001) with the organization. Based on this definition, trust in organization is 
important because it provides clues regarding how facilitative or supportive the organization is expected to be in reaction to employee's actions, how forgiving in case of mistakes, and how appreciative the organization is predicted to be in response to contributions the employee makes.

High levels of trust imply both predictable and benevolent reactions from the organization. Specifically, as defined by Bhattacharya, Devinney, and Pillutla (1998), trust is an expectancy of positive outcomes from the other party in the face of uncertainty. We contend that high trust in organization should amplify the connection between employee self-efficacy and positive outcomes. For example having confidence regarding how to perform one’s job better and contribute to one's environment indicate that the employee is highly motivated. Such motivation has the potential to be a boon to employee effectiveness and motivation to the extent to which the employee expects positive reactions to their actions. Employees who feels confident in their abilities to perform may exert effort to perform if they also believe that their efforts on behalf of the organization will be appreciated and valued. In contrast, when trust in organization is low, even employees who feel confident in their abilities cannot assume that their actions will be appreciated, valued, or reciprocated, or even that their efforts will be successful due to the possibility that the organization may not provide support when needed. Therefore, it is our contention that high trust in organization influences the strength of the relationship between selfefficacy and work-related outputs because it determines how much predictability and support may be expected from the organization.

Our study model is illustrated in Figure 1. As shown in the figure, we focused on four key outcomes that have predominantly been within the scope of self-efficacy and organizational trust studies, both theoretically and empirically. Specifically, self-efficacy has been related to job satisfaction (McNatt \& Judge, 2008), turnover intentions (Avey, Luthans, \& Jensen, 2009), task 
performance (Avey, Reichard, Luthans, \& Mhatre, 2011) and OCBs (Walumbwa, Hartnell, \& Oke, 2010). Job satisfaction, turnover intentions, task performance, and OCB are regarded as being among the top 10 most popular organizational behavior/human resources management and applied psychology research domains (Bernerth \& Aguinis, 2016), providing additional support for the importance and relevance of the selected outcomes.

\section{Employee Trust in Organization as a Moderator of Self-Efficacy}

SCT posits that changeability or controllability of the environment represents the level of system constraints and opportunities available for an employee to practice self-efficacy (Wood \& Bandura, 1989). Thus, the effect of self-efficacy on employee workplace outcomes should depend on employee trust in organization. According to Bandura (1988a: 288) "social environments differ in their opportunity structures, the constraints they place on personal efficacy and in their modifiability. Belief systems about the modifiability of the environment can affect the extent to which people take advantage of potential opportunities in the situations in which they find themselves.” Consistent with self-efficacy theory (Bandura, 1988a, 1997), previous theoretical studies of POB (Luthans \& Avolio, 2009) have predicted, and empirical research (Avey et al., 2011; Luthans et al., 2007) has affirmed that self-efficacy is a predictor of job satisfaction. Employees with greater confidence regarding their ability to make a difference at work will find their work environment more satisfying because they can create the conditions that will lead to their own satisfaction at work.

At the same time, we contend that this relationship will be affected by the level of trust in the organization. Job satisfaction refers to the degree to which employees are satisfied with such features of their job as the physical work conditions, the recognition they get for their good work, their immediate boss, their rate of pay, their opportunity to use their abilities, their chance of 
promotion, and attention paid to their suggestions (Warr, Cook, \& Wall, 1979). Employees with greater levels of self-efficacy may influence their own happiness at work by shaping their work environment to fit them better and satisfy their needs. Further, as theorized by Judge, Locke, and Durham (1997), employees with high self-efficacy will be more satisfied at work because they will be more effective. However, the "can do" attitude represented by self-efficacy needs to be supplemented with a "will do” aspect to facilitate its implications to have a higher job satisfaction (e.g., Chiaburu \& Lindsay, 2008). High trust in organization involves expectations of benevolence and predictability in interactions (Gabarro \& Athos, 1976), facilitating employee confidence to turn into action. Our thinking is supported by Dirks and Ferrin (2001) that trust affects how one expects the other party to behave in future interactions, which means that when trust is high, there is greater level of predictability regarding how the organization will react, encouracing confident employees to turn their motivation into action, affecting their own job satisfaction. Therefore, we propose that:

Hypothesis 1. Self-efficacy and trust in organization will interact to predict job satisfaction such that self-efficacy will be more positively related to job satisfaction for employees who have high levels of trust in organization, whereas the positive relationship will be weaker for employees who have low trust in organization.

Second, consistent with self-efficacy theory (Bandura, 1997), employees with high selfefficacy will be less likely to report high intent to quit their job. This is because self-efficacy affects turnover intentions through one’s choice of environment (Bandura, 1988a, 1997). Low self-efficacious employees "may elect to initially call in sick and then later quit, rather than face the frustration of a job they feel unable to do" whereas high self-efficacious employees "should feel better able to handle the surprise, disappointment, and stress of the workplace, and thus be 
less likely to feel the need to escape an otherwise unpleasant situation. Therefore, increasing employees’ self-efficacy may also lower their intention to quit ...” (McNattt \& Judge, 2008: 787, 788). This is also because SCT considers “choice behavior” of employees as an important determinant of their turnover intentions (Bandura, 1988a: 280). Accordingly, low self-efficacious employees are inclined to avoid activities and environments that they believe to surpass their coping capabilities because their failures create self-doubts, and, as a result, self-limitation (Bandura, 1988b), causing them to look for another job, whereas high self-efficacious employees accept challenging endeavors and social environments that they feel capable of managing well because their success in performance indicators strengthens their self-beliefs in their capabilities, causing them to stay with the current job (Bandura, 1994; Wood \& Bandura, 1989). This would suggest that employees with greater efficacy should be more persistent in trying to resolve organizational problems rather than looking to leave. Several studies, including a recent metaanalytical one, suggest that self-efficacy is negatively related to turnover intentions (e.g., Avey et al., 2011; Karatepe, 2015; Singh et al., 2013).

At the same time, social cognitive career theory has shown that self-efficacy interacts with the internal organizational environment to determine employees’ career, determining the extent of the opportunities and experiences they will be exposed to (Bandura, 2012; Lent, Brown, \& Hackett, 2002). High trust in organization provides an organizational environment where the relationship between self-efficacy and turnover intentions are negative and strong because by becoming fair, honest, predictable, truthful, and consistent to employees, the organization may assure employees that their honest efforts and cooperation with the organization to achieve mutually beneficial workplace outputs will be reciprocated by the organization in the form of fair promotion, recognition, and/or better development opportunities 
in the organization. In contrast, low trust in organization provides an environment where the relationship between self-efficacy and turnover intentions are weaker because these organizations may signal that even when the employee feels confident to act in ways that make their own environment more amenable, there is little reason to expect that the organization will look at these actions favorably. Thus, the relation between self-efficacy and turnover intentions should be more negative when trust in organization is high.

Hypothesis 2. Self-efficacy and trust in organization will interact to predict turnover intentions such that self-efficacy will be more negatively related to turnover intentions for employees who have high levels of trust in organization, whereas the negative relationship will be weaker for employees who have low trust in organization.

Task performance, an important and desired workplace behavior, is defined as the degree to which employees successfully complete work behaviors listed in their formal job definition such as completing assigned duties in time, fulfilling responsibilities specified in task description, and meeting performance requirements (Williams \& Anderson, 1991). Self-efficacy and job performance are related to one another so that the higher the employees' self-efficacy, the higher their level of motivation, effort and perseverance, and, as a result, the higher their performance will be (Bandura, 1982; Wood \& Bandura, 1989). There exists some empirical evidence that employees who have high self-efficacy show high task performance compared to employees who have lower self-efficacy (Avey et al., 2011; Raub \& Liao, 2012). Positive psychological capital, which includes self-efficacy as a subdimension (Luthans et al., 2006), has also been positively and significantly related to performance in meta-analytical studies (Avey et al., 2011). Employees who are convinced of their abilities to successfully execute different 
aspects of their jobs perform much better compared to those who are not similarly confident (Luthans et al., 2007).

At the same time, we predict that the positive relationship between self-efficacy and task performance is likely to be stronger among those employees who have high trust in organization because the expectation that the organization is benevolent and predictable will increase the likelihood that self-efficacy is positively related to success, and that their resulting behaviors are more likely to be appreciated and valued. Thus, the relation between self-efficacy and performance should be more positive when trust in organization is high. In contrast, low trust in organization introduces difficulties or setbacks such as not providing necessary information, equipment, tool, or support when needed, and lower confidence that the employee's actions will be appreciated and valued, leading to a weaker relationship between self-efficacy and task performance (Bandura, 1988a, 2009; Dirks \& Ferrin, 2001; Wood \& Bandura, 1989). Put another way, high trust in organization should amplify the desire to act on a task when one is confident regarding their capabilities, due to predictable and favorable reactions of the organization to persistent efforts of employees. Therefore, we propose that:

Hypothesis 3. Self-efficacy and trust in organization will interact to predict task performance such that self-efficacy will be more strongly and positively related to task performance for employees who have high levels of trust in organization, whereas the positive relationship will be weaker for employees who have low trust in organization. Finally, corresponding with self-efficacy theory (Bandura, 1997), those employees with high self-efficacy may also perform behaviors beyond their task requirements to perform citizenship behaviors. We predict that self-efficacy will be positively related to demonstrating subsequent behaviors such as high levels of attendance at work, giving advance notice when 
unable to come to work, and not complaining about insignificant things at work, which are the behaviors that benefit the organization in general, or OCBs (Williams \& Anderson, 1991). Studies have shown that self-efficacy is a positive predictor of OCBs in POB (Avey, Luthans, \& Youssef, 2010; Avey et al., 2011).

When employees perceive the organizational environment as reliable, fair, open and upfront with employees, those employees who have high self-efficacy are more likely to expand their role definition to include behaviors not present in their job description. Those employees who have high trust will expect their behaviors to be appreciated, valued, and rewarded by their organization (rule of reciprocity in social exchange theory) (Blau, 1964; Dirks \& Ferrin, 2001; Gouldner, 1960; Organ, 1990), strengthening the relationship between self-efficacy and OCBs. In contrast, those who experience low trust in organization will show a weaker link between selfefficacy and extra role behaviors because inconsistency, unpredictability, and the possibility of bad intentions associated with low organizational trust will weaken the desire of confident employees to engage in extra-role duties. In addition, those employees with high trust in organization may be more willing to engage in OCBs, when they have high self-efficacy because they trust in their organization to remove setbacks as much as possible, facilitating the persistency of efforts, cooperation, coordination, and perseverance in the activities/roles/tasks (Bandura, 2009; Breuer, Huffmeier, \& Hertel, 2016; Costa, Fulmer, \& Anderson, 2017). In other words, the motivation to perform OCBs will be higher among those who have high self-efficacy under the condition of high employee trust in organization. Therefore, we propose the following: Hypothesis 4. Self-efficacy and trust in organization will interact to predict OCBs such that self-efficacy will be more positively related to OCBs for employees who have high 
levels of trust in organization, whereas the positive relationship will be weaker for employees who have low trust in organization.

\section{Method}

\section{Sample and Procedures}

We collected data from employees and supervisors working in a heavy manufacturing company in Turkey. The company was ranked as one of the top ten companies in Turkey in terms of sales in 2016. The HR department aided us to collect data on site after we obtained the cooperation of the CEO of the company. Three separate surveys were distributed one month apart. The first two surveys were completed by employees, whereas the last survey was filled out by supervisors. The first survey captured trust in organization and demographics. The second employee survey included questions on self-efficacy, job satisfaction, and turnover intentions. Finally, the supervisor survey requested supervisors to rate each of their immediate subordinates on the extent to which they show task performance and OCBs.

We used a stratified random sampling strategy in which each employee in each department (stratum) was provided the same chance of being selected for the sample for the stratum. We used this sampling strategy because it was not possible to reach all employees of the company and, as a result, we wanted to ensure that all departments in the company were represented in our sample. The HR department facilitated the sample selection procedure by providing the necessary information.

A paper-and-pencil format was used in survey questionnaires. We invited 400 employees and their managers to participate in the study. Each participating employee was assigned a unique code number written on each of the surveys to match the data collected in different time periods. On the supervisor survey, supervisors were provided the employee name and the 


\section{TRUST IN ORGANIZATION}

identified code number and they were requested to write only the identified code number on the survey. We placed sealed collection boxes on the premises. The first author collected the boxes.

In the first survey we submitted 400 surveys and collected 363 completed surveys (response rate $=90.75 \%$ ). In the second survey, 363 surveys were distributed and 337 surveys were collected (response rate $=92.83 \%$ ). In the supervisor survey (the third survey), we distributed surveys to all 162 supervisors of 400 employees and received completed surveys from 149 supervisors (response rate $=91.97 \%$ ). After surveys with missing time periods and missing data were dropped, 300 dyads (300 employees (response rate $=75 \%$ for employees) and their 138 supervisors (response rate $=85.18 \%$ for employees' supervisors) were retained to test our four hypotheses. Of the 300 employees in the final sample, 92\% were male. The mean age of employees was 37 years $(S D=5)$. Employees came from departments including human resources, finance, engineering, marketing, production, accounting, and research \& development, among others. The mean organizational tenure of employees was 9.42 years $(\mathrm{SD}=5.06)$.

\section{Measures}

The original scales developed in English were translated into Turkish, following a backtranslation procedure (Brislin, Lonner, \& Thorndike, 1973). Two translators who are fluent both in Turkish and English collaborated in the language adaptation process. Each item was translated from English into Turkish by one of the bilingual speakers, and then the scales were re-translated into English by the second bilingual. First and final versions were compared in order to ensure equivalent meaning of each item. We created scale scores using the mean of all available responses from each individual. Response categories for the scales ranged from "strongly disagree” to "strongly agree”, unless otherwise stated. 
Self-efficacy. In order to measure self-efficacy, we used the 10 item RBSE scale by Parker (1998). We asked the respondents to report (using a 5-point scale, ranging from "no trust at all” to "complete trust”) the extent to which they trust themselves for each item. A sample item was “Analyzing a long-term problem to find a solution.” $(\alpha=.89)$

Trust in organization. For the measurement of trust in organization we used the trust scale by Gabarro and Athos (1976). The scale included seven items. We asked the respondents to state, on a 5-point Likert scale, the degree to which they agreed each item. A sample item was "I can expect my employer to treat me in a consistent and predictable fashion.” $(\alpha=.88)$

Job satisfaction. We measured job satisfaction levels of employees via the job satisfaction scale by Warr, Cook, and Wall (1979). We provided the participants a set of 15 items which deal with various aspects of their jobs. We asked them to rate, on a 7-point scale ranging from “very dissatisfied” to "very satisfied”. A sample item was "Your opportunity to use your abilities.” $(\alpha=.90)$

Turnover intentions. We assessed turnover intentions using the 7-point Likert-type intentions to quit scale by Wayne, Shore, and Liden (1997). The scale consisted of five items. A sample item was “As soon as I can find a better job, I’ll leave this company.” $(\alpha=.83)$

Task performance. We assessed task performance using the seven item scale developed by Williams and Anderson (1991). We asked supervisors to evaluate their subordinates on a 5point Likert scale for each item. A sample item was "This employee often fulfills responsibilities specified in job description.” $(\alpha=.89)$

Organizational citizenship behaviors. We used the seven item scale by Williams and Anderson (1991) to measure employees’ OCBs directed towards the organization. We asked supervisors to evaluate each of their subordinates on each item using a 5-point Likert scale. A 
TRUST IN ORGANIZATION

sample item was “This employee always conserves and protects organizational property.” $(\alpha=$ $.79)$

Control variables. Following past research (Tannenbaum, Mathieu, Salas, \& CannonBowers, 1991), we considered education, age, sex, and organizational tenure as potential control variables. Since age, sex, and organizational tenure did not correlate with any of the outcomes in our study, only years of education was controlled for in all analyses. Education is a theoretically meaningful covariate because it may be associated with job attitudes and behaviors, as well as self-efficacy levels, which means that any observed relation between self-efficacy and outcomes may reflect the relationship between education and outcomes. We report the results using education as a control, but we should also note that exclusion of education from our analyses do not result in a change in the significance level or direction of the results we report.

\section{Results}

Means, standard deviations, and correlations among variables are presented in Table 1.

Prior to testing our hypotheses, we conducted a series of Confirmatory Factor Analyses (CFA) to examine the construct validity of our measures. Specifically, due to the high correlation between performance and OCB $(r=.78, p<.01)$, as well as significant overlap between trust, performance, and OCB, we conducted a series of nested model comparisons. Due to the large number of items per scale, we created three parcels per latent variable in order to maintain a larger ratio of indicator to sample size (Landis, Beal, \& Tesluk, 2000). Our baseline model demonstrated adequate fit to the data $(\chi 2(\mathrm{df})=294.96(120), p<.01$, CFI $=.95$, RMSEA $=.07$, SRMR $=.047, \mathrm{NNFI}=.94)$. Further, this model fit the data significantly better than an alternative model where task performance and OCB $(\Delta \chi 2(\Delta \mathrm{df})=32.2(5), p<.01)$, trust and task performance, $\left(\Delta \chi^{2}(\Delta \mathrm{df})=303.85(5), p<.01\right)$, trust and OCB $\left(\Delta \chi^{2}(\Delta \mathrm{df})=288.15(5), p<.01\right)$, 
job satisfaction and task performance $(\Delta \chi 2(\Delta \mathrm{df})=279.39(5), p<.01)$, trust and job satisfaction $\left(\Delta \chi^{2}(\Delta \mathrm{df})=419.24(5), p<.01\right)$ and job satisfaction and OCB $\left(\Delta \chi^{2}(\Delta \mathrm{df})=352.44(5), p<.01\right)$ were specified to fall under a single factor. These analyses provided some evidence that despite the empirical overlap among variables, it was appropriate to treat them as separate.

We employed random coefficient regression procedures in Mplus 7.4 to test our hypotheses in order to account for the nested nature of our data, where 300 employees reported to 138 supervisors. Because the sample included clusters of employees reporting to the same manager, individual observations were naturally not independent of one another, potentially sharing substantial variation. The intraclass correlation coefficients (ICC) for the dependent variables were .38, .35, .24, and .38 for job satisfaction, turnover intentions, task performance, and OCBs respectively, suggesting that utilizing multilevel methodology not assuming independence of observations would be warranted (Snijders \& Bosker, 2012).

Models were specified with random intercepts and fixed slopes at the within-group level with outcome variables allowed to vary at within- and between-group levels. Models were estimated using the default maximum likelihood estimator with robust standard errors (MLR) in all analyses. Interaction term was created using the centered predictor variables. Significant interactions were probed using simple slope tests, with high and low values defined as one standard deviation above and below the mean (Aiken \& West, 1991).

When testing the hypotheses, we constructed three models for each dependent variable: job satisfaction, turnover intentions, task performance, and OCBs. In Model 1, we entered only the control variable (education in years, centered by grand mean) as the predictor of the intercept at within-level. In Model 2, we added centered self-efficacy and trust in organization as predictors of the intercept at the within-level. Finally, in Model 3 we entered the interaction term 


\section{TRUST IN ORGANIZATION}

of self-efficacy and trust in organization as predictors. We concluded that a hypothesis is supported whenever results revealed both a significant coefficient for the interaction term in Model 3 and a significant reduction in the deviance statistic between Model 2 and Model 3. Further, we examined reductions in Bayesian Information Criterion (BIC) across different models. Lower BIC values indicate better model fit. Based on Raftery (1995), a reduction of +10 in BIC between Models 2 and 3 indicates very strong evidence that Model 3 containing the interaction term is superior to the model, whereas a reduction of 6-10 indicates strong evidence, 2-6 indicating positive evidence and 0-2 indicating weak evidence.

The results reported in Table 2 indicate support for Hypothesis $1(t=2.12, p<.05)$. As illustrated in Figure 2, self-efficacy had a stronger positive relationship with job satisfaction when employees reported higher levels of trust in organization. Simple slope analyses indicated that self-efficacy had a positive relation with job satisfaction when trust in organization was high (estimate $=.73, \mathrm{SE}=.13, t=5.67, p<.01)$ but was not related to job satisfaction when trust in organization was low (estimate $=.19, \mathrm{SE}=.17, t=1.07, p>.05$ ).

The results of the analysis for Hypothesis 2 are also presented in Table 2. The interaction of trust and self-efficacy was significant with respect to turnover intentions $(t=-2.79, p<.01)$. The plot of the relationship presented in Figure 3 reveals a slightly different pattern of relationship between self-efficacy and turnover intentions for those higher and lower in organizational trust. Unexpectedly, self-efficacy had a positive relationship with turnover intentions. At the same time, when trust in organization was high, there was no relationship between self-efficacy and turnover intentions, whereas the relationship was positive when trust in organization was low. In other words, results support that trust in organization had a buffering role on the positive relationship between self-efficacy and turnover intentions. Simple slope 
analyses indicated that self-efficacy had a positive relation with turnover intentions when trust in organization was low (estimate $=.54, \mathrm{SE}=.18, t=3.00, p<.01$ ) but was not related to turnover intentions when trust in organization was high (estimate $=.07, \mathrm{SE}=.18, t=.39, p>.05$ ). These results fail to provide support for Hypothesis 2.

In Hypothesis 3, we predicted interaction effects on task performance. This hypothesis found support, as summarized in Table $3(t=2.82, p<.01)$. The nature of the interaction is shown in Figure 4. Simple slope analyses indicated that self-efficacy was positively related to task performance when trust in organization was high (estimate $=.39, \mathrm{SE}=.08, t=4.88, p<.01$ ) but was not related to task performance when trust in organization was low (estimate $=.01, \mathrm{SE}=.09$, $t=.09, p>.05)$. The results are supportive of the argument that trust in organization strengthens the positive relationship between self-efficacy and task performance, providing support for Hypothesis 3.

Finally Hypothesis 4 predicted that self-efficacy and trust in organization would interact to predict OCBs. The results presented in Table 3 are supportive of Hypothesis $4(t=2.12$, $p<.05)$. As illustrated in Figure 5 and the simple slope analyses, self-efficacy was positively related to OCBs when trust in organization was high (estimate $=.27, \mathrm{SE}=.08, t=3.19, p<.01$ ) but was not related to OCBs when trust in organization was low (estimate $=-.01$, SE $=.08, t=$ $.09, p>.05)$. Even though statistically significant, the results associated with this particular model are weaker than the remainder of the models. The reduction in BIC due to the introduction of the interaction term to the model is small (2.03) and the change in $\mathrm{R}^{2}$ associated with this model is modest (.02).

\section{Discussion}




\section{TRUST IN ORGANIZATION}

Given the importance of improving employees’ attitudes, behaviors, and performance and self-efficacy's prominent role in this improvement, an important gap in the literature is understanding the boundary conditions of the relationship between motivation and employee workplace outcomes. Drawing from SCT (Bandura, 2001, 2012), we examined employee trust in organization as an environmental boundary condition that could affect self-efficacy’s role on employee job satisfaction, turnover intentions, task performance, and OCBs. Consistent with our expectations, the relationship between self-efficacy and employee job attitudes and behaviors was conditional on employee trust in the system such that self-efficacy was more positively related to job satisfaction, task performance, and OCBs when trust in organization was high. Unexpectedly, self-efficacy and employee trust in organization interacted to predict turnover intentions such that self-efficacy was more positively related to turnover intentions for employees who had low levels of trust in organization, whereas the positive relationship was weaker for employees who had high trust in organization. All in all, our results provide support for our model that the effects of self-efficacy as a motivational construct on employee job satisfaction, performance, and OCBs were contingent upon the extent to which employees trust the organization, whereas we did not find support for this model with respect to turnover intentions.

We attribute the unexpected and, at the same time, interesting finding relating to turnover intentions to the fact that those employees high in self-efficacy may also end up emerging as those who will try to find a better job, look for a job outside the company, consider quitting their job, and seriously look for another job in the same industry. Similar results were observed in some prior research (e.g., Fast, Burris, \& Bartel, 2014; Jones, 1986; McNatt \& Judge, 2008), where self-efficacy emerged as a positive and significant predictor of turnover intentions and 
actual turnover. Specifically, those employees who are high in self-efficacy are better performers of their tasks and are convinced of their abilities and capabilities to successfully find another job and perform well in many different organizations. Our finding regarding employee turnover intentions means that those employees will leave the organization they do not trust because they believe in their capability to find another job in some other organization and that those employees who will not leave the organization they trust because they believe in their capability to work hard and succeed in the same organization.

\section{Theoretical Implications}

Theoretically, our results suggest that desired employee workplace attitudes and behaviors are the result of the interaction between high self-efficacy and high employee trust in organization. Specifically, we considered job satisfaction, turnover intentions, task performance, and OCBs as the most meaningful employee outcomes. Previous studies have mainly focused on the direct effect of self-efficacy on these outcomes. SCT (Bandura, 2001, 2012) argued that environment is a contingency factor regulating the effect of self-efficacy on task performance. We empirically showed and extended SCT that the effects of self-efficacy on job satisfaction, task performance, and OCBs are contingent upon the internal environment of an organization. Thus, our study clarifies the environmental effect of SCT on the effect of self-efficacy not only on the task performance as suggested by Bandura (2001, 2012) but also on the employee job satisfaction, task performance, and OCBs. Specifically, we add to and extend on SCT (Bandura, 2001, 2012) and self-efficacy theories (Bandura, 1997, 2012) by demonstrating that encouraging or discouraging characteristics of internal work environment determines the effect of an employee's trust in oneself on employee job satisfaction, turnover intentions, task performance, and OCBs. This theoretically means that high self-efficacy has stronger, positive, and significant 
effects on employee job satisfaction, task performance, and OCBs when the internal organizational environment is encouraging. When the internal organizational environment is discouraging, the positive effect of self-efficacy on the same employee outcomes turns out to be nonsignificant.

Further, our results point to the role employee trust in organization plays in enabling the effect of high self-efficacy and producing desired employee workplace attitudes and behaviors. To date, studies of trust literature have shown that trust in organization is positively associated with employee workplace attitudes and behaviors. Our results point out an additional path by which trust in organization is relevant to employee attitudes and behaviors: To those employees experiencing high levels of trust in organization, having a high level of self-efficacy is accompanied by higher job satisfaction, task performance, and OCBs. Thus, we provide empirical support to the theoretical work of Dirks and Ferrin (2001) that trust in organization moderates employee motivation and workplace behaviors and outcomes, and examining trust as a moderator adds value to the literature beyond an investigation of its main effects.

Our study should be interpreted within the context in which the study was conducted. Specifically, Turkish culture is characterized by collectivism, masculinity, high power distance, and high uncertainty avoidance (Hofstede, 1980), which might have affected employees' trust in organization (Doney, Cannon, \& Mullen, 1998; Rousseau, Sitkin, Burt, \& Camerer, 1998). The collectivist culture of Turkey may have increased the importance of trust in organization due to the importance of strong ties and cooperation with others (Doney et al., 1998; Whitener, Brodt, Korsgaard, \& Werner, 1998). Further, the moderator role of trust in organization may have been more pronounced due to the highly uncertainty avoidant nature of the cultural context. High uncertainty avoidance of Turkish culture might have affected perception and evaluation of risk 
(Doney et al., 1998), which means the role of trust in organization as a moderator may have been stronger.

The unexpected findings with respect to turnover intentions would benefit from further investigation. Unexpectedly, self-efficacy was positively related to both turnover intentions and job satisfaction, whereas job satisfaction was negatively related to turnover intentions. This finding may be context specific. For example, the nature of the industry may account for higher turnover intentions of employees with greater self-efficacy. Or, turnover intentions may reflect an action orientation that is higher among employees with greater efficacy. Further research into the nature of self-efficacy-turnover intentions relationship is warranted.

Our study has practical implications as well. The results of our study suggest that the work environment matters. When internal environment is favorable (high employee trust in organization), the investment made by organizations to increase self-efficacy of employees to produce desired workplace outcomes pays off by means of stronger job satisfaction, task performance, and OCBs. However, when the investment is made by the organization in an unfavorable internal environment (low employee trust in organization), having employees with high confidence seems to be less beneficial. Therefore, practicing managers should not only invest in increasing self-efficacy of their employees, but also invest in building trust so that employees experience less unpredictability and have a greater desire to benefit the organization.

\section{Potential Limitations and Future Research Directions}

Our study had a number of limitations, which point out avenues for future research. First, even though we took precautions to deal with the issue of common method bias, our study lacked a true longitudinal design. Specifically, as suggested by Podsakoff, MacKenzie, and Podsakoff (2012), we collected data at three time periods (temporal separation), and obtained task 
performance and OCB ratings from supervisors (source separation). At the same time, our findings cannot speak to the issue of causality and the direction of relationships among variables. This issue is particularly important to draw inferences regarding the direction of the trust-selfefficacy relationship. In our study, we considered trust in organization as largely independent from self-efficacy. The observed correlation between the two was significant but modest $(r=.12$, $p<.05)$. Even though our study suggests that trust in organization serves as a moderator of selfefficacy, it may also play a role in shaping up employee confidence to begin with. Studies investigating how trust in organization and self-efficacy shape over time would be useful to shed light on this issue.

Our test of the hypotheses included a sample from a heavy manufacturing organization. The manufacturing setting exhibits a dangerous working environment for employees. The high risk environment makes it unique to study the effects of self-efficacy on workplace intentions, behaviors, and outcomes, and understanding the boundary conditions of self-efficacy on the same employee outcomes in such an environment furthers our understanding. Yet, replication of our results is also required to increase generalizability to other high and less safety sensitive work environments. For example, our unexpected finding that self-efficacy was positively related to turnover intentions may be due to the relatively dangerous nature of the work performed - those employees who felt confident in their own abilities may have expressed a desire to leave if they could find a better job giving the hazardous and routine nature of work.

It is our understanding that time is ripe for further investigating the boundary conditions of the relationship between self-efficacy and employee workplace outcomes. We studied only one boundary condition, employee trust in organization. Because the internal environment of an organization includes many other environmental elements beyond employee trust in 
organization, future research should include organizational culture, climate (e.g., safety climate, justice climate, psychological climate), and perceived organizational support as other potential internal environmental elements that may serve as additional boundary conditions for the effect of self-efficacy on the employee workplace outcomes.

Finally, our sample consists of $92 \%$ male participants. This is typical of heavy manufacturing in Turkey (e.g., Erdogan, Ozyilmaz, Bauer, \& Emre, 2017), as well as other countries around the world (OECD, 2015). Previous studies on the effect of women engineers' self-efficacy on their work-related attitudes and behaviors (Singh et al., 2013), for example, revealed similar results with the studies which considered both female and male samples. There is some evidence that men have higher levels of RBSE compared to women (Axtell \& Parker, 2003; Parker, 1998). If this is the case, one possibility is that we may have oversampled high efficacy employees, but this possibility is not supported by our results where the average selfefficacy score was 3.73 out of 5.00. Still, in order to examine the generalizability of our results, it is important to replicate our findings in a more gender balanced sample.

\section{Conclusion}

In conclusion, we aimed to investigate the implications of a motivational construct, selfefficacy or an employee's trust in oneself, for employee attitudes and behaviors under the contingent effect of an encouraging or discouraging environment. High self-efficacy has benefits for organizations by means of increasing employee job satisfaction, task performance, and OCBs only when employee trust in organization is high. Low employee trust in organization weakens the benefits of self-efficacy on job satisfaction, turnover intentions, task performance, and OCBs. These results indicate that joint presence of high self-efficacy and high employee trust in 


\section{TRUST IN ORGANIZATION}

organization is required for organizations to reap all the benefits of self-efficacy on employee attitudes and behaviors. 


\section{References}

Aiken, L. S., \& West, S. G. (1991). Multiple regression: Testing and interpreting interactions. Newbury Park, CA: Sage Publications.

Alfes, K., Shantz, A., \& Truss, C. (2012). The link between perceived HRM practices, performance and well-being: The moderating effect of trust in employer. Human Resource Management Journal, 22, 409-427. doi: 10.1111/1748-8583.12005

Aryee, S., Budhwar, P. S., \& Chen, Z. X. (2002). Trust as a mediator of the relationship between organizational justice and work outcomes: Test of a social exchange model. Journal of Organizational Behavior, 23, 267-285. doi: 10.1002/job.138

Avey, J. B., Luthans, F., \& Jensen, S. M. (2009). Psychological capital: A positive resource for combating employee stress and turnover. Human Resource Management, 48, 677-693. doi: 10.1002/hrm.20294

Avey, J. B., Luthans, F., \& Youssef, C. M. (2010). The additive value of positive psychological capital in predicting work attitudes and behaviors. Journal of Management, 36, 430-452. doi: 10.1177/0149206308329961

Avey, J. B., Reichard, R. J., Luthans, F., \& Mhatre, K. H. (2011). Meta-analysis of the impact of positive psychological capital on employee attitudes, behaviors, and performance. Human Resource Development Quarterly, 22, 127-152. doi: 10.1002/hrdq.20070

Axtell, C. M., \& Parker, S. K. (2003). Promoting role breadth self-efficacy through involvement, work redesign and training. Human Relations, 56, 113-131. doi:

$10.1177 / 0018726703056001452$

Bandura, A. (1982). Self-efficacy mechanism in human agency. American Psychologist, 37, 122147. doi: 10.1037/0003-066X.37.2.122 
Bandura, A. (1988a). Organizational applications of social cognitive theory. Australian Journal of Management, 13, 275-302. doi: 10.1177/031289628801300210

Bandura, A. (1988b). Self-regulation of motivation and action through goal systems. In V. Hamilton, G. H. Bower, \& N. H. Frijda (Eds.), Cognitive perspectives on emotion and motivation (pp. 37-61). Dordrecht, Netherlands: Kluwer Academic Publishers.

Bandura, A. (1994). Self-efficacy. In V. S. Ramachaudran (Ed.), Encyclopedia of human behavior (pp. 71-81). New York: Academic Press. (Reprinted in H. Friedmen [Ed.], Encyclopedia of mental health. San Diego: Academic Press, 1998.

Bandura, A. (1997). Self-efficacy: The exercise of control. New York, NY: Freeman.

Bandura, A. (2001). Social cognitive theory: An agentic perspective. Annual Review of Psychology, 51, 1-26. doi: 10.1146/annurev.psych.52.1.1

Bandura, A. (2009). Cultivate self-efficacy for personal and organizational effectiveness. In E. A. Locke (Ed.), Handbook of principles of organization behavior (pp. 179-200). New York: Wiley.

Bandura, A. (2012). On the functional properties of perceived self-efficacy revisited. Journal of Management, 38, 9-44. doi: 10.1177/0149206311410606

Bernerth, J. B., \& Aguinis, H. (2016). A critical review and best-practice recommendations for control variable usage. Personnel Psychology, 69, 229-283. doi: 10.1111/peps.12103

Bhattacharya, R., Devinney, T. M., \& Pillutla, M. M. (1998). A formal model of trust based on outcomes. Academy of Management Review, 23, 459-472. doi:

10.5465/AMR.1998.926621

Blau, P. (1964). Exchange and power in social life. New York, NY: Wiley. 
Brislin, R. W., Lonner, W. J., \& Thorndike, R. M. (1973). Cross-cultural research methods. New York, NY: J. Wiley.

Breuer, C., Huffmeier, J., \& Hertel, G. (2016). Does trust matter more in virtual teams? A metaanalysis of trust and team effectiveness considering virtuality and documentation as moderators. Journal of Applied Psychology, 101, 1151-1177. doi: 10.1037/apl0000113

Brown, G., Crossley, C., \& Robinson, S. L. (2014). Psychological ownership, territorial behavior, and being perceived as a team contributor: The critical role of trust in the work environment. Personnel Psychology, 67, 463-485. doi: 10.1111/peps.12048

Chen, G., Casper, W. J., \& Cortina, J. M. (2001). The roles of self-efficacy and task complexity in the relationships among cognitive ability, conscientiousness, and work-related performance: A meta-analytical examination. Human Performance, 14, 209-230. doi: 10.1207/S15327043HUP1403_1

Chiaburu, D. S., \& Lindsay, D. R. (2008). Can do or will do? The importance of self-efficacy and instrumentality for training transfer. Human Resource Development International, 11, 199-206. doi: 10.1080/13678860801933004

Colquitt, J. A., \& Rodell, J. B. (2011). Justice, trust, and trustworthiness: A longitudinal analysis integrating three theoretical perspectives. Academy of Management Journal, 54, 11831206. doi: 10.5465/amj.2007.0572

Colquitt, J. A., Scott, B. A., \& LePine, J. A. (2007). Trust, trustworthiness, and trust propensity: A meta-analytic test of their unique relationships with risk taking and job performance. Journal of Applied Psychology, 92, 909-927. doi: 10.1037/0021-9010.92.4.909 
Costa, A. C., Fulmer, C. A., \& Anderson, N. R. (2017). Trust in work teams: An integrative review, multilevel model, and future directions. Journal of Organizational Behavior. doi: 10.1002/job.2213

Cropanzano, R., Anthony, E. L., Daniels, S. R., \& Hall, A. V. (2017). Social exchange theory: A critical review with theoretical remedies. Academy of Management Annals, 11, 1-38. doi: 10.5465/annals.2015.0099

Crossley, C. D., Cooper, C. D., \& Wernsing, T. S. (2013). Making things happen through challenging goals: Leader proactivity, trust, and business-unit performance. Journal of Applied Psychology, 98, 540-549. doi: 10.1037/a0031807

Dirks, K. T., \& Ferrin, D. L. (2001). The role of trust in organizational settings. Organization Science, 12, 450-467. doi: 10.1287/orsc.12.4.450.10640

Dirks, K. T., \& Ferrin, D. L. (2002). Trust in leadership: Meta-analytic findings and implications for research and practice. Journal of Applied Psychology, 87, 611-628. doi: 10.1037/0021-9010.87.4.611

Doney, P. M., Cannon, J. P., \& Mullen, M. R. (1998). Understanding the influence of national culture on the development of trust. Academy of Management Review, 23, 601-620. doi: 10.5465/AMR.1998.926629

Erdogan, B., Ozyilmaz, A., Bauer, T. N., \& Emre, O. (2017). Accidents happen: Psychological empowerment as a moderator of accident involvement and its outcomes. Personnel Psychology. doi: 10.1111/peps.12228

Fast, N. J., Burris, E. R., \& Bartel, C. A. (2014). Managing to stay in the dark: Managerial selfefficacy, ego defensiveness, and the aversion to employee voice. Academy of Management Journal, 57, 1013-1034. doi: 10.5465/amj.2012.0393 


\section{TRUST IN ORGANIZATION}

Fulmer, C. A., \& Gelfand, M. J. (2012). At what level (and whom) we trust: Trust across multiple organizational levels. Journal of Management, 38, 1167-1230. doi: $10.1177 / 0149206312439327$

Gabarro, J. J., \& Athos, J. (1976). Interpersonal relations and communications. Englewood Cliffs, NJ: Prentice Hall.

Gouldner, A. W. (1960). The norm of reciprocity: A preliminary statement. American Sociological Review, 25, 161-178.

Hofstede, G. (1980). Culture’s consequences. Beverly Hills, CA: Sage.

Huang, L., \& Luthans, F. (2015). Toward a better understanding of the learning goal orientationcreativity relationship: The role of positive psychological capital. Applied Psychology: An International Review, 64, 444-472. doi: 10.1111/apps.12028

Jones, G. (1986). Socialization tactics, self-efficacy, and newcomers’ adjustments to organizations. Academy of Management Journal, 29, 262-279. doi: 10.2307/256188

Judge, T. A., \& Bono, J. E. (2001). Relationship of core self-evaluations traits-self-esteem, generalized self-efficacy, locus of control, and emotional stability-with job satisfaction and job performance: A meta-analysis. Journal of Applied Psychology, 86, 80-92. doi: 10.1037//0021-9010.86.1.80

Judge, T. A., Jackson, C., Shaw, J. C., Scott, B. A., \& Rich, B. L. (2007). Self-efficacy and work-related performance: The integral role of individual differences. Journal of Applied Psychology, 92, 107-127. doi: 10.1037/0021-9010.92.1.107

Judge, T. A., Locke, E. A., \& Durham, C. C. (1997). The dispositional causes of job satisfaction: A core evaluations approach. Research in Organizational Behavior, 19, 151-188. 


\section{TRUST IN ORGANIZATION}

Karatepe, O. M. (2015). Do personal resources mediate the effect of perceived organizational support on emotional exhaustion and job outcomes? International Journal of Contemporary Hospitality Management, 27, 4-26. doi: 10.1108/IJCHM-09-2013-0417

Kramer, R. M. (1999). Trust and distrust in organizations: Emerging perspectives, enduring questions. Annual Review of Psychology, 50, 569-598. doi:

10.1146/annurev.psych.50.1.569

Kramer, R. M. (2010). Collective trust within organizations: Conceptual foundations and empirical insights. Corporate Reputation Review, 13, 82-97. doi: 10.1057/crr.2010.9

Landis, R. S., Beal, D. J., \& Tesluk, P. E. (2000). A comparison of approaches in forming composite measures in structural equation models. Organizational Research Methods, 3, 187-207. doi: 10.1177/109442810032003

Lent, R. W., Brown, S. D., \& Hackett, G. (2002). Social cognitive career theory. In D. Brown (Ed.), Career development and choice (pp. 255-311). San Francisco, CA: Jossey-Bass.

Lumineau, F. (2017). How contracts influence trust and distrust. Journal of Management, 43, 1553-1577. doi:10.1177/0149206314556656

Luthans, F., Avey, J. B., Avolio, B. J., Norman, S. M., \& Combs, G. M. (2006). Psychological capital development: Toward a micro-intervention. Journal of Organizational Behavior, 27, 387-393. doi: 10.1002/job.373

Luthans, F., \& Avolio, B. J. (2009). The “point” of positive organizational behavior. Journal of Organizational Behavior, 30, 291-307. doi: 10.1002/job.589

Luthans, F., Avolio, B. J., Avey, J. B., \& Norman, S. M. (2007). Positive psychological capital: Measurement and relationship with performance and satisfaction. Personnel Psychology, 60, 541-572. doi: 10.1111/j.1744-6570.2007.00083 
Luthans, F., \& Youssef, C. M. (2007). Emerging positive organizational behavior. Journal of Management. 33, 321-349. doi: 10.1177/0149206307300814

Mayer, R. C., Davis, J. H., \& Schoorman, F. D. (1995). An integrative model of organizational trust. Academy of Management Review, 20, 709-734. doi: 10.5465/AMR.1995.950808033

McAllister, D. J. (1995). Affect- and cognition-based trust as foundations for interpersonal cooperation in organizations. Academy of Management Journal, 38, 24-59. doi: $10.2307 / 256727$

McEvily, B., Perrone, V., \& Zaheer, A. (2003). Trust as an organizing principle. Organization Science, 14, 91-103. doi: 10.1287/orsc.14.1.91.12814

McNatt, D. B., \& Judge, T. (2008). Self-efficacy intervention, job attitudes, and turnover: A field experiment with employees in role transition. Human Relations, 61, 783-810. doi: $10.1177 / 0018726708092404$

OECD (Organization for Economic Co-operation and Development) (2015). Distribution of employment by aggregate sector and sex. Retrieved on April 26, 2017 from http://www.oecd.org/gender/data/employment/

O'Neill, B. S., \& Mone, M. A. (1998). Investigating equity sensitivity as a moderator of relations between self-efficacy and workplace attitudes. Journal of Applied Psychology, 83, 805816. doi: 10.1037/0021-9010.83.5.805

Organ, D. W. (1990). The motivational basis of organizational citizenship behavior. In B. M. Staw, \& L. L. Cummings (Eds.), Research in organizational behavior (pp. 43-72). Greenwich, CT: JAI Press. 
Parker, S. K. (1998). Enhancing role breadth self-efficacy: The roles of job enrichment and other organizational interventions. Journal of Applied Psychology, 83, 835-852. doi: 10.1037/0021-9010.93.1.8

Podsakoff, P. M., MacKenzie, S. B., \& Podsakoff, N. P. (2012). Sources of method bias in social science research and recommendations on how to control it. Annual Review of Psychology, 63, 539-569. doi: 10.1146/annurev-psych-120710-100452

Raftery, A. E. (1995). Bayesian model selection in social research. Sociological Methodology, 25, 111-163. doi: 10.2307/271063

Raghuram, S., Wiesenfeld, B., \& Garud, R. (2003). Technology enabled work: The role of selfefficacy in determining telecommuter adjustment and structuring behavior. Journal of Vocational Behavior, 63, 180-198. doi: 10.1016/S0001-8791(03)00040-X

Raub, S., \& Liao, H. (2012). Doing the right thing without being told: Joint effects of initiative climate and general self-efficacy on employee proactive customer service performance. Journal of Applied Psychology, 97, 651-667. doi: 10.1037/a0026736

Rousseau, D. M., Sitkin, S. B., Burt, R. S., \& Camerer, C. (1998). Not so different after all: A cross-discipline view of trust. Academy of Management Review, 23, 393-404. doi: 10.5465/AMR.1998.926617

Schaubroeck, J. M., Shen, Y., \& Chong, S. (2017). A dual-stage moderated mediation model linking authoritarian leadership to follower outcomes. Journal of Applied Psychology, 102, 203-214. doi: 10.1037/apl0000165

Singh, R., Fouad, N. A., Fitzpatrick, M. E., Liu, J. P., Cappaert, K. J., \& Figuereido, C. (2013). Stemming the tide: Predicting women engineers’ intentions to leave. Journal of Vocational Behavior, 83, 281-294. doi: 10.1016/j.jvb.2013.05.007 
Snijders, T. A. B., \& Bosker, R. J. (2012). Multilevel analysis: An introduction to basic and advanced multilevel modeling. Thousand Oaks, CA: Sage.

Stajkovic, D., \& Luthans, F. (1998a). Self-efficacy and work-related performance: A metaanalysis. Psychological Bulletin, 124, 240-261. doi: 10.1037/0033-2909.124.2.240

Stajkovic, D., \& Luthans, F. (1998b). Social cognitive theory and self-efficacy: Going beyond traditional motivational and behavioral approaches. Organizational Dynamics, 26, 62-74. doi: 10.1016/S0090-2616(98)90006-7

Tannenbaum, S. I., Mathieu, J. E., Salas, E., \& Cannon-Bowers, J. A. (1991). Meeting trainees' expectations: The influence of training fulfillment on the development of commitment, self-efficacy, and motivation. Journal of Applied Psychology, 76, 759-769. doi: 10.1037//0021-9010.76.6.759

Vancouver, J. B., \& Kendall, L. N. (2006). When self-efficacy negatively relates to motivation and performance in a learning context. Journal of Applied Psychology, 91, 1146-1153. doi: 10.1037/0021-9010.91.5.1146

Walumbwa, F. O., Hartnell, C. A., \& Oke, A. (2010). Servant leadership, procedural justice climate, service climate, employee attitudes, and organizational citizenship behavior: A cross-level investigation. Journal of Applied Psychology, 95, 517-529. doi: 10.1037/a0018867

Warr, P., Cook, J., \& Wall, T. (1979). Scales for the measurement of some work attitudes and aspects of psychological well-being. Journal of Occupational Psychology, 52, 129-148. doi: 10.1111/j.2044-8325.1979.tb00448 
Wayne, S. J., Shore, L. M., \& Liden, R. C. (1997). Perceived organizational support and leadermember exchange: A social exchange perspective. Academy of Management Journal, 40, 82-111. doi: 10.2307/257021

Whitener, E. M., Brodt, S. E., Korsgaard, M. A., \& Werner, J. M. (1998). Managers as initiators of trust. An exchange relationship framework for understanding managerial trustworthy behavior. Academy of Management Review, 23, 513-530. doi:

10.5465/AMR.1998.926624

Williams, L. J., \& Anderson, S. E. (1991). Job satisfaction and organizational commitment as predictors of organizational citizenship and in-role behaviors. Journal of Management, 17, 601-617. doi: 10.1177/014920639101700305

Wood, R., \& Bandura, A. (1989). Social cognitive theory of organizational management. Academy of Management Review, 14, 361-384. doi: 10.5465/AMR.1989.4279067

Wu, C., Parker, S. K., Wu, L., \& Lee, C. (2017). When and why people engage in different forms of proactive behavior: Interactive effects of self-construals and work characteristics. Academy of Management Journal. doi: 10.5465/amj.2013.1064 
Running head: TRUST IN ORGANIZATION

Table 1

Means, Standard Deviations, and Intercorrelations among Variables

\begin{tabular}{|c|c|c|c|c|c|c|c|c|c|c|}
\hline Variable & 1 & 2 & 3 & 4 & 5 & 6 & 7 & 8 & 9 & 10 \\
\hline 1. Self-efficacy (T2E) & - & & & & & & & & & \\
\hline 2. Trust in organization (T1E) & $.12 *$ & - & & & & & & & & \\
\hline 3. Job satisfaction (T2E) & $.34^{* *}$ & $.44^{* *}$ & - & & & & & & & \\
\hline 4. Turnover intentions (T2E) & $.18^{* *}$ & $-.31 * *$ & $-.30 * *$ & - & & & & & & \\
\hline 5. Task performance (T3M) & $.27 * *$ & $.53^{* *}$ & $.59 * *$ & $-.28 * *$ & - & & & & & \\
\hline 6. OCB (ТЗМ) & $.22 * *$ & $.55^{* *}$ & $.49 * *$ & $-.27 * *$ & $.78 * *$ & - & & & & \\
\hline 7. Education (T1E) & $.22 * *$ & -.14 & -.02 & $.18 * *$ & .08 & .09 & - & & & \\
\hline 8. Age (T1E) & .05 & -.02 & -.01 & -.00 & -.11 & -.10 & $-.14 *$ & - & & \\
\hline 9. Sex (T1E) & -.03 & -.05 & -.07 & -.02 & .01 & .01 & $.16^{* *}$ & $-.16 * *$ & - & \\
\hline 10. Tenure (T1E) & .09 & -.02 & .06 & -.00 & -.03 & -.01 & -.05 & $.64 * *$ & $-.16^{* *}$ & - \\
\hline$M$ & 3.73 & 3.78 & 4.55 & 3.39 & 3.97 & 3.84 & 12.12 & 37.37 & - & 9.42 \\
\hline$S D$ & .63 & .68 & .87 & 1.24 & .64 & .66 & 2.81 & 5.04 & - & 5.06 \\
\hline Skewness & -.21 & -1.08 & -.65 & .54 & -1.05 & -.96 & -.57 & .23 & 3.19 & 2.18 \\
\hline Kurtosis & -.75 & 1.89 & 2.49 & .21 & 1.35 & 1.38 & .03 & -.21 & 8.24 & 4.62 \\
\hline
\end{tabular}

$n=299-300$. Sex was coded as $1=$ female, $0=$ male. OCB is Organizational citizenship behaviors. Education is level of education in years. Tenure is organizational tenure in years. Task performance and organizational citizenship behaviors were reported by supervisors of employees. * $p<.05$; ** $p<.01$. T2 is one month after T1. T3 is one month after T2. E and M denote measurement perspective (Employee and Manager respectively). 
TRUST IN ORGANIZATION

Table 2

Tests of Hypothesis 1 and 2

\begin{tabular}{|c|c|c|c|c|c|c|c|c|c|c|c|c|c|c|c|c|c|c|}
\hline \multirow[b]{3}{*}{ Variable } & \multicolumn{9}{|c|}{ Job Satisfaction } & \multicolumn{9}{|c|}{ Turnover Intentions } \\
\hline & \multicolumn{3}{|c|}{ Model 1} & \multicolumn{3}{|c|}{ Model 2} & \multicolumn{3}{|c|}{ Model 3} & \multicolumn{3}{|c|}{ Model 1} & \multicolumn{3}{|c|}{ Model 2} & \multicolumn{3}{|c|}{ Model 3} \\
\hline & Estimate & $\overline{S E}$ & $\mathrm{t}$ & Estimate & SE & $\mathrm{T}$ & Estimate & SE & $\mathrm{t}$ & Estimate & SE & $\mathrm{T}$ & Estimate & SE & $\mathrm{T}$ & Estimate & SE & $\mathrm{t}$ \\
\hline Intercept & 4.58 & .06 & $76.97^{* *}$ & 4.56 & .05 & $95.25^{* *}$ & 4.54 & .05 & $90.56^{* *}$ & 3.41 & .09 & $38.56^{* *}$ & 3.41 & .08 & $41.51^{* *}$ & 3.44 & .08 & $41.25^{* *}$ \\
\hline Education & -.01 & .02 & -.72 & -.01 & .01 & -1.04 & -.01 & .01 & -.74 & .06 & .03 & $2.16^{*}$ & .03 & .03 & 1.03 & .02 & .03 & .78 \\
\hline $\begin{array}{l}\text { Trust in } \\
\text { organization }\end{array}$ & & & & .53 & .11 & $4.83^{* *}$ & .52 & .10 & $5.33^{* *}$ & & & & -.60 & .11 & $-5.29 * *$ & -.60 & .11 & $-5.62 * *$ \\
\hline Self-efficacy & & & & .42 & .10 & $4.34 * *$ & .46 & .08 & $5.78^{* *}$ & & & & .37 & .14 & $2.57^{*}$ & .30 & .13 & $2.33^{*}$ \\
\hline $\begin{array}{l}\text { Trust in } \\
\text { organization } \\
\text { x Self- } \\
\text { efficacy }\end{array}$ & & & & & & & .41 & .19 & $2.12^{*}$ & & & & & & & -.53 & .19 & $-2.79 * *$ \\
\hline $\begin{array}{l}\text { Deviance } \\
\text { (-2*log } \\
\text { likelihood) }\end{array}$ & & 754.99 & & & 662.23 & & & 645.68 & & & 947.81 & & & 907.92 & & & 895.71 & \\
\hline df & & 1 & & & 3 & & & 4 & & & 1 & & & 3 & & & 4 & \\
\hline $\begin{array}{l}\text { Deviance } \\
\text { change }\end{array}$ & & & & & $92.76^{* *}$ & & & $16.54 * *$ & & & & & & $39.89 *$ & & & $12.21^{* *}$ & \\
\hline BIC & & 777.81 & & & 696.45 & & & 685.61 & & & 970.63 & & & 942.14 & & & 935.63 & \\
\hline$\Delta \mathrm{BIC}$ & & & & & 81.36 & & & 10.84 & & & & & & 28.49 & & & 6.51 & \\
\hline
\end{tabular}


TRUST IN ORGANIZATION

$R^{2}$

$\Delta R^{2}$
.00
.27

.04
.00

11

.11

$n=300$.

$* p<.05 ; * * p<.01$. 
Table 3

Tests of Hypothesis 3 and 4

\begin{tabular}{|c|c|c|c|c|c|c|c|c|c|c|c|c|c|c|c|c|c|c|}
\hline \multirow[b]{3}{*}{ Variable } & \multicolumn{9}{|c|}{ Task Performance } & \multicolumn{9}{|c|}{ Organizational Citizenship Behaviors } \\
\hline & Model 1 & & & Model 2 & & & Model 3 & & & Model 1 & & & Model 2 & & & Model 3 & & \\
\hline & Estimate & SE & $\mathrm{t}$ & Estimate & SE & $\mathrm{t}$ & Estimate & SE & $\mathrm{t}$ & Estimate & SE & $\mathrm{T}$ & Estimate & SE & $\mathrm{t}$ & Estimate & SE & $\mathrm{t}$ \\
\hline Intercept & 3.98 & .05 & $87.53^{* *}$ & 3.97 & .04 & $114.99 * *$ & 3.95 & .04 & $108.32 * *$ & 3.84 & .05 & $81.48^{* *}$ & 3.83 & .04 & $106.89 * *$ & 3.82 & .04 & $103.03^{* *}$ \\
\hline Education & .02 & .01 & 1.12 & .03 & .01 & $1.98 *$ & .03 & .01 & $2.12 *$ & .02 & .01 & 1.42 & .03 & .01 & $2.88 * *$ & .03 & .01 & $3.10 * *$ \\
\hline $\begin{array}{l}\text { Trust in } \\
\text { organization }\end{array}$ & & & & .46 & .06 & $7.55^{* *}$ & .45 & .05 & $8.32 * *$ & & & & .52 & .07 & $7.39 * *$ & .51 & .07 & $7.46^{* *}$ \\
\hline $\begin{array}{l}\text { Self- } \\
\text { efficacy }\end{array}$ & & & & .17 & .06 & $2.91^{* *}$ & .20 & .05 & $3.84 * *$ & & & & .11 & .06 & 1.91 & .13 & .05 & $2.45^{*}$ \\
\hline $\begin{array}{l}\text { Trust in } \\
\text { organization } \\
\text { x Self- } \\
\text { efficacy }\end{array}$ & & & & & & & .28 & .10 & $2.82 * *$ & & & & & & & .20 & .10 & $2.12 *$ \\
\hline $\begin{array}{l}\text { Deviance } \\
(-2 * \log \\
\text { likelihood) }\end{array}$ & 545.10 & & & 451.57 & & & 435.83 & & & 569.51 & & & 464.91 & & & 457.17 & & \\
\hline $\mathrm{df}$ & 1 & & & 3 & & & 4 & & & 1 & & & 3 & & & 4 & & \\
\hline $\begin{array}{l}\text { Deviance } \\
\text { change }\end{array}$ & & & & $93.53^{* *}$ & & & $15.75^{* *}$ & & & & & & $104.60 * *$ & & & $7.74 * *$ & & \\
\hline
\end{tabular}


TRUST IN ORGANIZATION

\begin{tabular}{lllllll}
\hline BIC & 567.92 & 485.80 & 475.75 & 592.33 & 499.13 & \\
$\Delta \mathrm{BIC}$ & & 82.12 & 10.05 & & 93.2 & \\
$R^{2}$ & .00 & .11 & .18 & .00 & .20 & .20 \\
$\Delta R^{2}$ & & .11 & .07 & .22 & .02 \\
\hline
\end{tabular}

$n=300$.

$* p<.05 ;{ }^{* *} p<.01$. 
Running head: TRUST IN ORGANIZATION

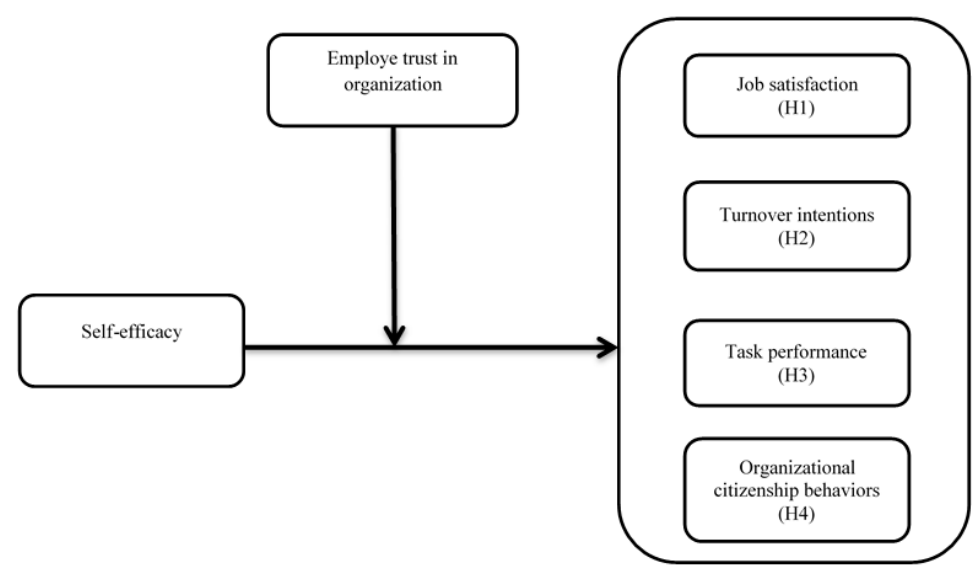

Figure 1. Study model. 


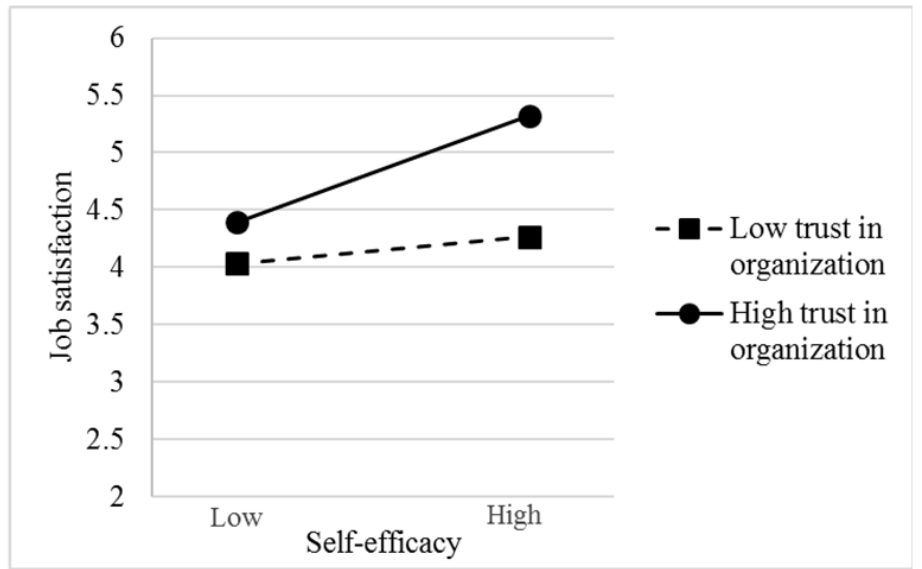

Figure 2. Interaction of self-efficacy and trust in organization to predict job satisfaction. 
TRUST IN ORGANIZATION

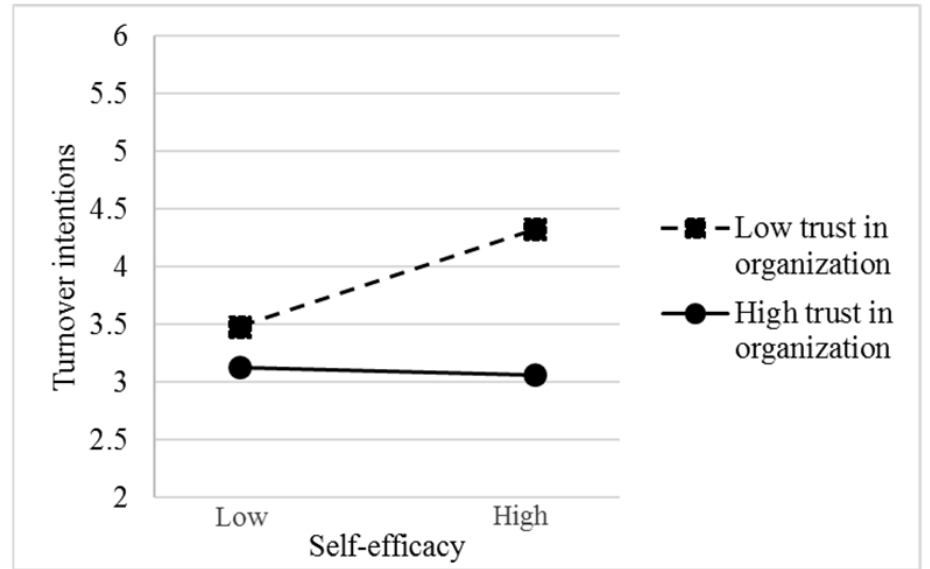

Figure 3. Interaction of self-efficacy and trust in organization to predict turnover intentions. 


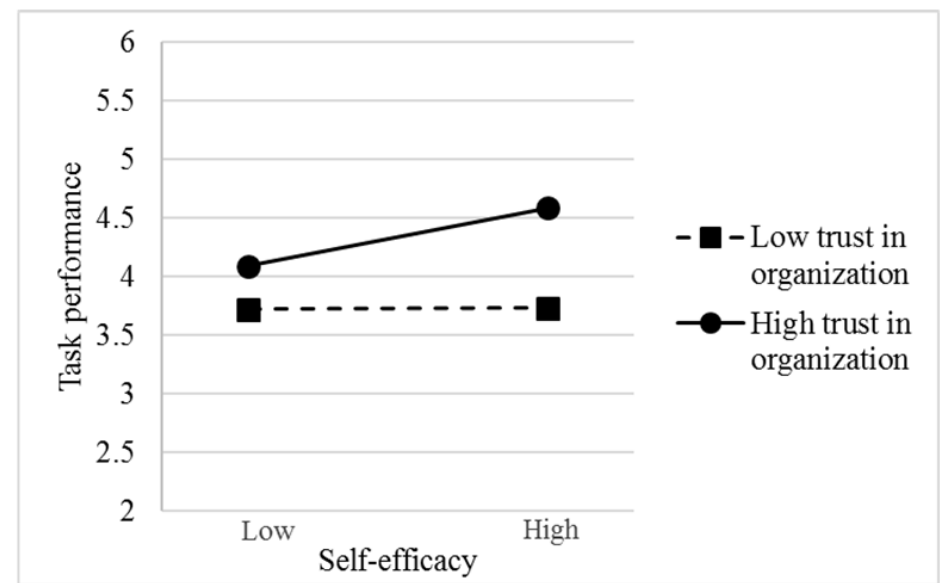

Figure 4. Interaction of self-efficacy and trust in organization to predict task performance. 


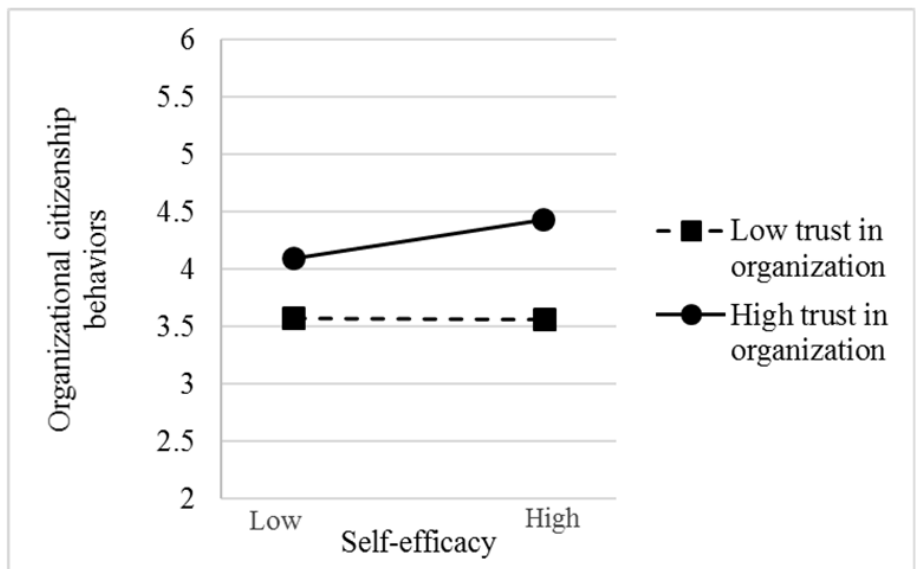

Figure 5. Interaction of self-efficacy and trust in organization to predict organizational citizenship behaviors. 